\title{
Aino Piehl
}

\section{Klarspråkskampanj som maktmedel?}

Den finländska klarspråkskampanjen vill uppmuntra myndigheter att göra klarspråkssatsningar och att visa exempel, vara förebilder och presentera lyckade resultat. I kampanjen deltar sju pilotmyndigheter och deras åtgärder presenteras på kampanjens webbplats. Via tävlingen "Den bästa framgångsberättelsen" vill kampanjen också föra fram exempel på nya metoder som myndigheterna har tagit i bruk för att förbättra sitt skrivande. Metoderna representerar mjuk makt (se Josehp Nye), medan hård makt skulle innebära att staten använde lagar eller föreskrifter för att påverka myndigheternas beteende. Båda former av makt behövs emellertid om myndigheterna ska styras till att följa rekommendationerna i det nya handlingsprogrammet för ett klarare myndighetsspråk.

På den internationella klarspråksdagen 2014 inleddes i Finland en klarspråkskampanj, som kommer att pågå till slutet av år 2015. Målet för kampanjen är att uppmuntra statliga och kommunala myndigheter att förbättra sitt språk och skriva fler lättlästa texter. På vilket sätt borde kampanjens arrangörer fästa avseende vid begreppet makt? Det har talats mycket om myndighetsspråk som medel för maktutövning gentemot medborgarna, men vem har makt att påverka myndigheternas språk? Kan också en klarspråkskampanj vara maktutövning?

\section{Klarspråkskampanjen har sina rötter i handlingsprogrammet för klart myn- dighetsspråk}

Klarspråkskampanjen är en följd av det handlingsprogram för klart myndighetsspråk som färdigställdes 2014 på initiativ av Finlands regering. Avsikten med programmet är att statliga och kommunala myndigheter i högre grad ska följa $9 \$$ i förvaltningslagen, 
där det föreskrivs att myndigheterna ska använda ett sakligt, klart och begripligt språk. Programmet innehåller förslag till åtgärder, av vilka en del är avsedda för regeringen och riksdagen, en del för enskilda myndigheter och en del för universitet och andra institutioner som utbildar framtida tjänstemän. Rekommendationerna handlar om olika sätt att ordna skrivandet av texter och sörja för att skribenternas färdigheter utvecklas och att man får respons på texterna (Piehl 2013).

En av rekommendationerna i handlingsprogrammet är att regeringen ska göra åtgärderna i programmet kända genom en klarspråkskampanj. Kampanjen är också ett av Finlands åtaganden inom ramen för det internationella projektet Open Government Partnership. De länder som deltar i projektet har förbundit sig att främja en öppen förvaltning genom konkreta åtgärder. Över 60 länder deltar, bland dem alla de nordiska länderna. Deltagarländerna ska vartannat år utarbeta en handlingsplan där deras åtaganden presenteras, och Finland är hittills det enda land där planerna omfattar främjande av klarspråk på myndigheterna.

Projektet för en öppen förvaltning leds av Finansministeriet, som också är en av klarspråkskampanjens arrangörer. Det största ansvaret för innehållet vilar på Institutet för de inhemska språken, som är officiellt expertorgan när det gäller klarspråk. Andra arrangörer är Undervisnings- och kulturministeriet, statsrådets kansli, Folkpensionsanstalten (FPA), kommunernas intresseorganisation Kommunförbundet och Selkokeskus (det finska centret för lättläst text). Arrangörerna samlas regelbundet för att följa utvecklingen och planera för framtiden.

\section{Förebilder och exempel motiverar}

För att myndigheterna ska bli intresserade av att följa rekommendationerna i handlingsprogrammet för klart myndighetsspråk måste kampanjen väcka deras uppmärksamhet. Åtgärderna får inte heller vara svåra att genomföra i det dagliga arbetet. Därför erbjuder kampanjen såväl redskap för myndigheterna att bedöma sin egen språkliga situation som exempel på den nytta som andra myndigheter haft av att utveckla sina texter och förbättra skrivpraxis.

Erfarenheten visar att det främst är andra myndigheters exempel som lockar myndigheter att delta i språkliga projekt. Därför har kanslichef Harri Pursiainen vid Kommunikationsministeriet inbjudits att fungera som fadder för kampanjen. Han har medverkat såväl vid invigningen av kampanjen som på kampanjens webbplats och $\mathrm{i}$ sociala medier. I motiverande syfte har också statsministern och undervisningsministern ombetts att komma med en hälsning och statssekreteraren vid statsrådets kansli, riksdagens justitieombudsman och andra intressanta tjänstemän att bidra med kolumner. Dessutom har Finansministeriet, som svarar för utveckling av förvaltningen, presenterat kampanjen för statsförvaltningen vid olika tillställningar som ministeriet ordnat. 
Förebilder erbjuder kampanjen framför allt genom att presentera verksamheten vid pilotmyndigheterna. Kampanjen har sju pilotmyndigheter som valt ut olika rekommendationer i handlingsprogrammet som de vill följa. De sju är Kommunikationsministeriet, Trafiksäkerhetsverket (Trafi), Folkpensionsanstalten (FPA), Migrationsverket, Skatteförvaltningen, Tammerfors stad och Vasa stad. Inom pilotprojekten vid FPA, Skatteförvaltningen och Vasa stad utvecklar man sina färdigheter i att skriva texter på två språk. På kampanjens webbplats presenteras pilotprojektens planer och nyheter från projekten. Pilotmyndigheterna har kontaktpersoner vid Institutet för de inhemska språken, och egna evenemang ordnas för dessa myndigheter under kampanjen.

Exempel erbjuder kampanjen också genom att berätta om god praxis vid andra myndigheter. Därför pågår tävlingen Framgångsberättelser, som tar emot information från myndigheterna själva eller från vem som helst om lyckade metoder. De tävlande presenteras på webbplatsen. Ett exempel är informationsprocessen vid Migrationsverket, där man genom välriktad information och förbättrade texter har lyckats få telefonförfrågningarna om uppehållstillstånd för studenter att minska till en fjärdedel av det tidigare antalet. Tävlingen avslutas med att allmänheten får rösta fram en segrare, och den som utvecklat de bästa metoderna får ett pris vid kampanjens avslutningsceremoni.

\section{Hjälpmedel på nätet}

Kampanjen vill hjälpa myndigheterna att komma i gång med sitt eget klarspråksarbete. På de finska kampanjsidorna finns det material som kan utgöra underlag för diskussioner till exempel om kvaliteten på de egna texterna, om behovet av lättläst text eller om praxis när det gäller namn på myndigheter. Där finns också fyra finska test som gäller utvärdering av såväl skrivpraxis och metoder för namngivning som av enskilda namn och enskilda texter (förebild för det sistnämnda testet är det svenska Klarspråkstestet). Man kan också printa ut affischer med principer för gott myndighetsspråk.

Också andra än myndigheter kan delta i tävlingen Framgångsberättelser. På kampanjsidorna finns det dessutom en textverkstad, där finska myndighetstexter kan läggas ut för kommentarer och bearbetning. De texter som hittills lagts ut har i allmänhet varit sådana som myndigheterna hållit på att förnya, och den myndighet som lagt ut en text har kommenterat allmänhetens förslag och svarat på frågor. På detta sätt har olika slag av texter bearbetats: ett pressmeddelande, ett kundbrev och en myndighetsföreskrift. En särskilt populär uppgift har varit att utarbeta lättlästa anvisningar för skattekort. För arbetet i verkstaden ges tips som gäller olika textgenrer. Verkstaden erbjuder också myndigheterna ett nytt sätt att få respons på sina texter.

Kampanjen äger i huvudsak rum på webbplatsen. Där läggs minst en gång i veckan ut nytt innehåll eller nyheter om klarspråk. Också humoristiska texter om myndig- 
hetsspråk har lagts ut där. Webbplatsen är en del av Språkinstitutets finska klarspråkssidor, och den redigeras av Språkinstitutets experter på myndighetsspråk. Kampanjen har också en Facebooksida med i huvudsak samma innehåll som webbplatsen. Meddelanden om nyheter finns på Språkinstituts Twitterkonto. Flest retweetar har meddelanden om textverkstaden och nyheter om pilotmyndigheterna gett upphov till.

\section{Mjuk och hård makt i klarspråkskampanjen}

Exempel, förebilder och resultat på myndigheter är metoder som kampanjen använder för att locka myndigheterna att handla. Dessa metoder kallas av den amerikanske politikforskaren Joseph Nye för mjuk makt. Han använder termerna mjuk makt och hård makt för att beskriva relationer mellan stater. Hård makt utövas genom avtal eller lagar och genom ekonomisk eller militär påtryckning, medan mjuk makt lockar till efterföljelse genom att man visar att de egna metoderna leder till framgång och välstånd.

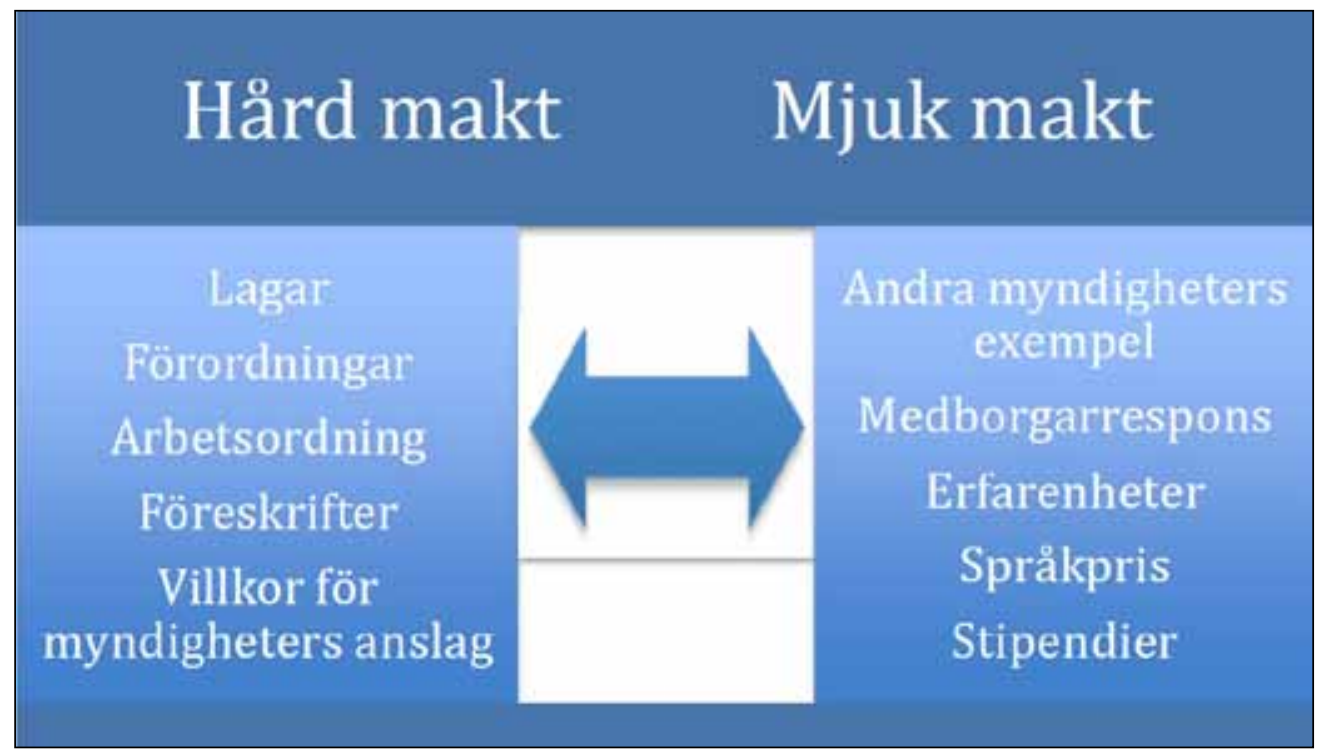

Hård och mjuk makt i klarspråksarbete

Om termerna mjuk makt och hård makt tillämpas på klarspråksarbetet är mjuk makt att presentera god praxis och dess följder och att berätta om stöd från inflytelserika grupper. Hård makt representeras av föreskrifter i lag eller från myndigheter om ett önskvärt handlingssätt. Finländska språkvårdare är vana vid att använda mjuk makt, för någon hård makt har de inte.

\section{Hård makt i klarspråkskampanjen}

Mjuk makt har fungerat väl i klarspråkskampanjen. Webbplatsen har haft rikligt med 
besökare, och medierna har uppmärksammat kampanjen och pilotmyndigheterna. De sistnämnda har blivit ombedda att presentera sin verksamhet, och det har redan hänt att andra följt deras exempel. Kampanjen har lett till att myndigheterna startat klarspråksgrupper, beställt skrivutbildning och bett om hjälp med att förnya brevmallar och andra standardtexter.

Det behövs dock också hård makt för att sätta hela förvaltningen i rörelse, och det enda sättet att utöva sådan makt när det gäller att utveckla myndighetsspråket är att övertyga makthavarna om att det är nödvändigt. Institutet för de inhemska språken har talat med politiker och inflytelserika tjänstemän för att lyckas få igenom de rekommendationer i handlingsprogrammet för klart myndighetsspråk som enskilda myndigheter inte kan besluta om. Sådana rekommendationer är till exempel att en tjänst som nationell klarspråksombudsman ska inrättas, att en lag om ortnamn ska stiftas, att en termbank och en textbank för förvaltningen ska grundas, att mål som gäller språket ska tas upp i ministeriernas årsplaner och följas upp i årsrapporteringen samt att gemensamma utbildningsprogram för myndighetsspråk ska startas.

Tidpunkten är exceptionellt svår när det gäller nya klarspråksprojekt i Finland. För det första: handlingsprogrammet färdigställdes och kampanjen inleddes i slutet av en valperiod. Efter valet bildade nya partier regering och ministrarna byttes ut. För det andra: Finlands ekonomiska situation har försvagats ytterligare, och hårda nedskärningar är att vänta inom den offentliga förvaltningen. Det är alltså inte lätt att få regeringen eller ministerierna att utfärda nya lagar och förordningar och att använda pengar på permanenta arrangemang eller stora projekt.

\section{Är hård makt effektivare än mjuk makt?}

Med mjuk makt kan man påverka politikerna och de ledande tjänstemännen, alltså dem som använder hård makt. Just nu håller kampanjens arrangörer på att tillsammans med Jord- och skogsbruksministeriet utarbeta en nätkurs i gott myndighetsspråk. Principen är att de olika parterna först utarbetar utbildnings- eller nätmaterial för sin egen organisation. Sedan ska materialet sammanställas och bearbetas så att det blir en självstudiekurs. Om resultatet blir lyckat kan kursen i sinom tid användas som en grundkurs för alla tjänstemän. Då skulle man genom att använda hård makt kunna kräva att hela tjänstemannakåren genomgår kursen, liksom alla i dag måste genomgå en obligatorisk kurs i informationssäkerhet.

Det är dock också viktigt att minnas den hårda maktens begränsningar. Inom förvaltningen har man erfarenhet av att föreskrifter följs bara formellt, så att den avsedda nyttan inte uppnås i verkligheten. Konsekvensbedömning av lagförslag är till exempel en obligatorisk och övervakad del av lagberedningen. I många lagprojekt görs dock bedömningen i praktiken snabbt utan utredningar och undersökningar. Sådana lagprojekt måste godkännas, eftersom det inte finns tid och pengar för något annat. Bristen 
på tid för införande av nya rutiner är ofta ett hinder även när det gäller att förbättra myndighetsspråket.

Mjuk makt kan rent av vara effektivare än hård makt, om den kan användas till att väcka myndigheternas egen vilja att införa nya rutiner. Det är detta som klarspråkskampanjen i huvudsak bygger på.

\section{Summary}

The Finnish Government's Plain Language Campaign (2014-2015) encourages government agencies to improve their texts and communication by presenting free plain language tools and good practice on its website. Examples are given by the campaign's seven pilot agencies, whose plain language projects can be followed on the campaign website. A competition for best practices is another way to disseminate new ways of achieving clear texts and proper communication. These methods may be said to represent soft power (cf. Joseph Nye), but hard power is also necessary: permanent structures must be put in place by legislation or administrative decisions. In the end, it is hard to tell which tool is the more efficient. If writing practices are to be changed, there must be a desire to do better, and that is more likely to be stimulated by using soft power.

\section{Litteraturförteckning}

Klart myndighetsspråk - ett handlingsprogram, 2014: Undervisnings- och kulturministeriets arbetsgruppspromemorior och utredningar 2014: 3, http://www.minedu.fi/export/sites/ default/OPM/Julkaisut/2014/liitteet/tro3.pdf?lang=s v

Nye, Joseph, 1990: Bound to Lead: The Changing Nature of American Power. New York: Basic Books. Open Government Partnership (September 2015): http://www.opengovpartnership.org/

Piehl, Aino, 2014: Klart myndighetsspråk - ett handlingsprogram. I: Maria Andersson, Eivor Sommardahl \& Aino Piehl (red.): Myndighetstexterur medborgarperspektiv - Rapport från Nordisk klarspråkskonferens i Helsingfors 21-22.11.2013, Skrifter 9 - Institutet för de inhemska språken, s. 45-52. Helsingfors: Institutet för de inhemska språken i Finland, http://ojs.statsbiblioteket. $\mathrm{dk} /$ index.php/ksn/article/view/20429

Projektet Öppen förvaltning (september 2015): http://vm.fi/sv/forvaltningens-oppenhet/oppenforvaltning

Finlands Kommunförbunds klarspråksplanscher (september 2015): http://www.kommunerna.net/ sv/sakkunnigtjanster/information/klarsprak/bank/material/Sidor/argument.aspx

Den finländska klarspråkskampanjen (januar 2016): www.kotus.fi/virkakieli 


\section{Bibliografiske oplysninger}

Piehl, Aino, 2016: Klarspråkskampanj som maktmedel? I: Fra myndig maktspråk til klar kommunikasjon · Rapport fra Nordisk klarspråkskonferanse Oslo 28.-29. mai 2015, 83-89.

http://ojs.statsbiblioteket.dk/index.php/ksn

C Författarna och Nätverket för språknämnderna i Norden 
